\title{
脱灰石炭造粒粒子の解砕による石炭一重油一水 混合物の静置安定性
}

\author{
Static Stability of Coal-Oil-Water Mixture Prepared by \\ Disintegration of Deashed Coal Agglomerates
}

\author{
高 瀬均 *, 宮 崎 修 治* \\ Hitoshi TAKASE, Shuji MIYAZAKI
}

\begin{abstract}
The static stability of COW (Coal- Oil- Water Mixture), which is made by the disintegration of deashed coal agglomerates, is investigated. The static stability is evaluated by two methods, that is, the direct measurement of coal volume fraction in COW and the rod penetration test. When the static stability of COW is high, the difference of coal volume fraction between the upper section and the lower section of the storage column is small, and the 50\% diameters of coal particles in both sections are almost equal in size. On the other hand, when the static stability of COW is low, the coal volume fraction becomes large in the lower section, and in contrast the water volume fraction becomes large in the upper section. It is found that the rod penetration test only shows whether the hardpack layer of coal particles is formed on the column bottom. An empirical equation, which represents the degree of the static stability of COW, is obtained.
\end{abstract}

Key Words : COW, Static Stability, Yield Value, Deashed Coal Agglomerate

\section{1. 緒言}

エネルギー資源の枯渇化が懸念される中において, 石炭は現在においても世界的に見ればその埋蔵量は 膨大である。しかし，我が国の石炭資源は少なく， 現在, 石炭消費量のほとんどを海外から輸入してい る" 。これより我が国では, 輸入炭, 国内産炭を問わ ず，石炭資源の一層の有効利用がなされねばならな い。石炭可燃成分の含有量の少ない低品位炭の脱灰に よる高品位化は, 石炭資源の有効利用法の一つとし て，今後ますますその重要度が増すと考えられる。著

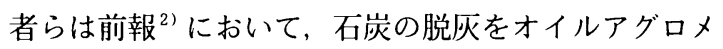
レーション法. 4) により行い, 得られた脱灰石炭造粒 粒子を添加剂が無添加の条件で再び解砕して, 石炭一 重油一水混合物（以後， COW と呼ぶ）を製造し，そ の流動特性について検討した。その結果，製造された $\mathrm{COW}$ は，30 50 ${ }^{\circ} \mathrm{C}$ の条件においてビンガム流動性

1998年 9 月 7 日受付

* 富山大学工学部物質生命システム工学科

（率930-8555 富山市五福3190） TEL 0764-45-6830

Department of Material Systems Engineering and Life Science. Toyama University

(3190 Gofuku, Toyama-shi 930-8555)
を示し,ずり速度が $10 \mathrm{~s}^{-1}$ の条件でみかけ粘度が 0.33 ４.0Pa・s となることを示した。

$\mathrm{COW}$ は, 石炭の流体化エネルギーとして, 主にボ イラーなどで燃焼させて利用されることが考えられ る。COW の製造地と消費地が異なる場合，COW は 製造 $\rightarrow$ 貯蔵 $\rightarrow$ 輸送 $\rightarrow$ 貯蔵 $\rightarrow$ 燃焼という経路をたどって 利用されることになる。本研究では，COW の町蔵が タンク内など静置下で行われることを仮定して, 静 置条件下での COW の安定性について検討を行う。 COW の静置安定性が良いとは, 静置前後で静置容器 内の各地点における石炭, 重油, 水の容積分率の変化 が小さいことを意味する。静置安定性が悪い場合, 静 置後, 静置容器の上部と下部では COW 中の成分割合 が大きく異なる。このような状態の COW を使う場合 には, 前処理として COW 中の成分の再均一化を行う 必要が生じる。静置安定性が極度に悪い場合には, 容 器底部付近に石炭粒子の沈降圧密層であるハードパッ ク層が形成される。ハードパック層は堅固であり, こ れを破壊して再び容器中で各成分の均一化を行うこと はかなり困難である。

本研究では, $\mathrm{COW}$ の静置安定性について, 静置後 の COW 中の各成分の容積分率測定, 特に石炭粒子の 
容積分率測定の結果に基つく検討を中心にして行う。 また，同時に現場サイドでよく利用される棒貫入法試 験を行い, 各成分の容積分率測定の結果との関係など から, 同試験より得られる結果の意味について考察す る。

\section{2. 実験方法}

\section{1 静置安定性試験装置}

前報 ${ }^{21}$ において脱灰石炭造粒粒子から COW を製造 したが，その COW の一部が前報での COW の流動特 性の測定に使われ，残りの COW を本研究での静置安 定性試験に用いた。COW 製造時に混入した気泡の除 去操作後，スパチュラで $\mathrm{COW}$ を十分に混合し，その 後直径 $4 \mathrm{~cm}$, 高さ $22 \mathrm{~cm}$ の円筒型の静置安定性試験 容器に $18 \mathrm{~cm}$ の高さまで COW を入れた。静置安定性 試験容器は, 透明アクリル樹脂製で上端は解放されて おり，底部には取り外しのできる底板が付けてある。 次に, 試験容器上部をフイルムで密封し, これを恒温 槽内に静置した。静置温度を $30,40,50{ }^{\circ} \mathrm{C}$ とし, 静置期間を 10 日間とした。COW 中の石炭, 重油 ( A 重油と C 重油の混合重油), 水の平均容積分率, $\phi_{\mathrm{vc} 0}$, $\phi_{\mathrm{vo} 0}, \phi_{\mathrm{vw0} 0}$ を，それぞれ $0.26 \sim 0.37 ， 0.48 \sim 0.62$, $0.10 \sim 0.19$ の範囲内で変化させた。また，これを石 炭, 重油, 水の平均重量分率, $\phi_{\mathrm{wc} 0}, \phi_{\mathrm{wo} 0}, \phi_{\mathrm{ww} 0}$ の変 化で表すと，それぞれ $0.37 \sim 0.49 ， 0.38 \sim 0.51$, 0.09 0.18 となる。Table 1, Fig. 1に, COW 中の石

Table 1 Properties of coal

Ultimate analysis

(dry ash free basis) (\%)

$\begin{array}{ccccccc}\mathrm{C} & \mathrm{H} & \mathrm{O} & \mathrm{N} & \mathrm{S} & \rho_{\mathrm{c}}\left(\mathrm{kg} \cdot \mathrm{m}^{-3}\right) & d_{50}(\mathrm{~m}) \\ 81.9 & 5.0 & 10.7 & 1.9 & 0.5 & 1.50 \times 10^{3} & 1.03 \times 10^{-5}\end{array}$

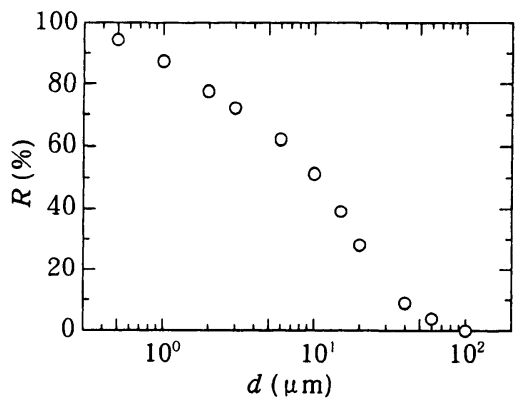

Fig. 1 Particle size distribution of coal in COW
Table 2 Properties of mixed heavy oil

\begin{tabular}{cccc}
$T$ & $\rho_{\mathrm{o}}$ & $\mu_{\mathrm{o}}$ & $\begin{array}{c}\gamma_{\mathrm{ow}} \\
\left(\mathrm{N} \cdot \mathrm{m}^{-1}\right)\end{array}$ \\
30 & $8.90 \times 10^{2}$ & 53.0 & $2.49 \times 10^{-2}$ \\
40 & $8.83 \times 10^{2}$ & 32.2 & $2.55 \times 10^{-2}$ \\
50 & $8.76 \times 10^{2}$ & 21.0 & $2.64 \times 10^{-2}$ \\
\hline
\end{tabular}

炭の物性および遠心沈降式粒度分布測定装置（島津製 作所，SA-CP3）で測定された粒子径分布を示す。 乾燥石炭中の灰分含有率は $10.5 \%$ である。Table 2 に, $\mathrm{COW}$ 中の重油の物性を示す。

\section{2 静置安定性の判定法}

\section{2.1 成分容積分率測定}

（1）各成分の容積分率測定法

10 日間の静置後, 静置安定性試験容器内の各成分 の容積分率測定を，以下のように行った。測定位置 を, 試験容器底部から $1,3,7,11,15,17 \mathrm{~cm}$ の高さ の位置とした。静置終了後, 試験容器を $4{ }^{\circ} \mathrm{C}$ に保っ た恒温槽に入れて, COW を冷却, 固化させた。次 に, 試験容器上部の密封のためのフイルムおよび底板 を取り外し, 直径 $3.9 \mathrm{~cm}$, 厚さ $2 \mathrm{~cm}$ の円板を先端に 付けた押し出し棒で, 試験容器内から固化した $\mathrm{COW}$ を押し出した。COW 柱から各測定高さを中心にして 厚さ約 $1 \mathrm{~cm}$ の円板状部分を切り取り，その重量 $w_{\mathrm{t}}$ を 測定した。

円板状 COW 中の各成分の容積分率を, 次の方法で 求めた。まず，円板状 COW を幾つかに分割してそれ ぞれ重量を求めた後これらを以下の測定に用いた。 COW 中の石炭重量測定を次のように行った。分割さ れた COW の 1 個を約 $50^{\circ} \mathrm{C}$ に温めたへキサン中に入 れて擋拌し, COW 中の重油の洗い出しを行った後, これをろ過した。万過後，COW 中の石炭粒子はろ紙 (ADVANTEC 社，GF75）上に分離される。へキサン による重油の洗い出しが不十分な場合には，万液がも とのへキサンと同じ色となるまで，乃紙上の石炭粒 子に更にヘキサンを掛けて洗浄した。へキサン洗浄 後, 乃紙上の分離石炭粒子の乾燥重量を測定し, 分割 された COW ともとの円板状 COW との重量比から， 冈板状 COW 中の全石炭重量 $w_{\mathrm{c}}$ を算出した。円板状 $\mathrm{COW}$ 中の全水分重量 $w_{\mathrm{w}}$ を, 次のように求めた。分 割された COW 数個中の水分重量を, JIS K 2275 「原油及び石油製品水分試験方法」の蒸留法により求 め, 円板状 $\mathrm{COW}$ 重量之分割された $\mathrm{COW}$ 数個の重量 との比から $w_{\mathrm{w}}$ を求めた。円板状 $\mathrm{COW}$ 中の全重油重 
量 $w_{\mathrm{o}}$ を, $w_{\mathrm{t}}$ から $w_{\mathrm{c}}, w_{\mathrm{w}}$ を差し引いて求めた。これ より, 各成分の静置温度における密度を使うことによ り, 各測定高さにおける石炭容積分率 $\phi_{\mathrm{vc}}$ は, Eq. (1) により求められる。

$$
\phi_{\mathrm{vc}}=\frac{\frac{w_{\mathrm{c}}}{\rho_{\mathrm{c}}}}{\frac{w_{\mathrm{c}}}{\rho_{\mathrm{c}}}+\frac{w_{\mathrm{o}}}{\rho_{\mathrm{o}}}+\frac{w_{\mathrm{w}}}{\rho_{\mathrm{w}}}}
$$

重油, 水の容積分率 $\phi_{\mathrm{vo}}, \phi_{\mathrm{vw}}$ も, Eq. (1) と同様な式 により求められる。

（2）静置安定性の判定

静置安定性試験容器の底部から $1 \mathrm{~cm}$ と $17 \mathrm{~cm}$ の高 さの位置における石炭容積分率 $\phi_{\mathrm{cv} 1}, \phi_{\mathrm{vcl} 17}$ を使っ て, Eq. (2) により石炭容積分率測定に基づく静置安 定性指数 $\psi_{\mathrm{c}}$ を定義した。

$$
\psi_{\mathrm{c}}=\frac{\left|\phi_{\mathrm{vc} 1}-\phi_{\mathrm{vc} 17}\right|}{\phi_{\mathrm{vc} 0}}
$$

本研究では, $\psi_{\mathrm{c}}$ の值を基準として, 成分容積分率測 定に基づくCOW の静置安定性の判定を行った。すな わち， $\psi_{\mathrm{c}} \leq 0.1$ のとき静置安定性が良いと判定し， $\psi_{\mathrm{c}}$ $>0.1$ のとき静置安定性が悪いと判定した。また, Eq. （3）により水の容積分率に基づく静置安定性指数 $\psi_{\mathrm{w}}$ を定義し， $\psi_{\mathrm{c}}$ との関係について検討した。

$$
\psi_{\mathrm{w}}=\frac{\left|\phi_{\mathrm{vw} 1}-\phi_{\mathrm{vw} 17}\right|}{\phi_{\mathrm{vw} 0}}
$$

\section{2.2 棒貫入法試験}

棒貫入法試験は，スラリーの安定性を定性的に簡便 に判定するために行われる方法である。棒貫入法試験 は, 石炭スラリーである $\mathrm{COM}^{5)}$ や $\mathrm{CWM}^{6,7)}$ の安定性 の判定法としてもよく行われているが, 貫入棒の大き さ, 重量, あるいは安定性の判定基準は様々である。

本研究では, 棒貫入法試験に基づく COW の静置安 定性の判定を, 以下のように行った。静置期間終了 後, 前記の COW の固化操作の前に, 静置安定性試験 容器内の $\mathrm{COW}$ 上端面よりガラス棒（直径 $0.5 \mathrm{~cm}$, 長さ $45 \mathrm{~cm}$, 重さ $20 \mathrm{~g}$ ）を垂直に落下させ, ガラス棒 先端位置と経過時間を測定した。このとき, ガラス棒 が試験容器底部まで達した場合, COW の静置安定性 は良いと判定した。これに対し, 落下途中において 3 分間以上落下距離がゼロとなった場合, COW の静置 安定性は覀いと判定した。ガラス棒が落下しなくなる のは, ガラス棒の先端が石炭粒子のハードパック層に

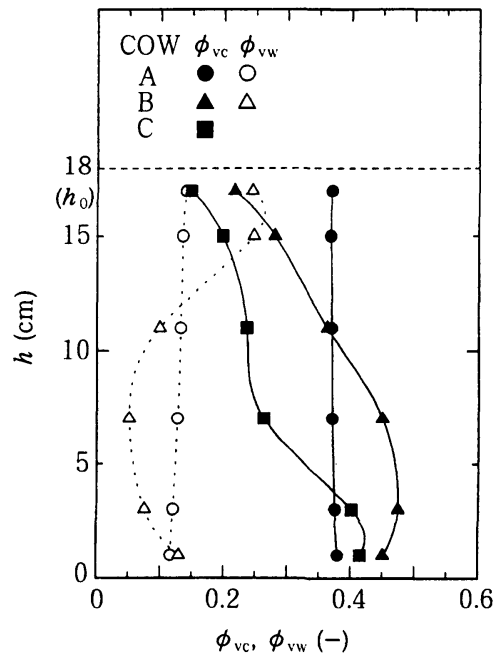

Fig. 2 Volume fraction of coal and water in COW after 10 days storage

達したためである。前記 2.2.1 項の COW 中の各成分 の容積分率測定においては, COW 中にガラス棒を落 下させたことによる影響を無視した。

\section{3. 実験結果および考察}

\section{3. $1 \mathrm{COW}$ の静置安定性}

\section{1.1 石炭容積分率測定による判定}

Fig. 2 に，COW を 10 日間静置させた後の, 静置安 定性試験容器内の各高さ $h$ における, 石炭と水の容積 分率 $\phi_{\mathrm{vc}}, \phi_{\mathrm{vw}}$ の測定結果を示す。 $\mathrm{COW} \mathrm{A}\left(\phi_{\mathrm{vc} 0}\right.$ : $\left.\phi_{\mathrm{v} 00}: \phi_{\mathrm{vw} 0}=0.37: 0.50: 0.13, T=30^{\circ} \mathrm{C}\right)$ の場合, $\phi_{\mathrm{vc}}$, $\phi_{\mathrm{vw}}$ は試験容器内の各高さでほぼ同じ值を示してお り, 静置期間中に COW 中の分散石炭粒子および分 散水滴はほとんど移動していないことがわかる。これ に対し, COW A と同じ成分組成で静置温度 $T$ を高く した COW B $\left(\phi_{\mathrm{vc} 0}: \phi_{\mathrm{vo} 0}: \phi_{\mathrm{vw} 0}=0.37: 0.50: 0.13, T=\right.$ $\left.50^{\circ} \mathrm{C}\right)$ の場合, $\phi_{\mathrm{vc}}$ は試験容器下部で大きくなり, $\phi_{\mathrm{vw}}$ は試験容器上部で大きくなっている。これは静置中 に, 連続相である重油との密度差が水滴に比較してょ り大きい石炭粒子が下方へ沈降し, これに伴い重油よ り密度は大きいものの密度差が小さい水滴が上方へ押 し出されたためと考えられる。 $\mathrm{COW} C\left(\phi_{\mathrm{vc} 0}: \phi_{\mathrm{vo} 0}\right.$ : $\left.\phi_{\mathrm{vw} 0}=0.27: 0.60: 0.13, T=30^{\circ} \mathrm{C}\right)$ については $\phi_{\mathrm{vc}}$ の結 果のみを示したが, この場合も $\phi_{\mathrm{vc}}$ は試験容器底部へ 向かうほど大きくなり, 石炭粒子の沈降が起きている ことがわかる。静置安定性指数 $\psi_{\mathrm{c}}$ により各 COW の 静置安定性を判定すると， COW A は $\psi_{\mathrm{c}} \leq 0.1$ とな り静置安定性は良く, COW B, C は $\psi_{\mathrm{c}}>0.1$ となるこ 


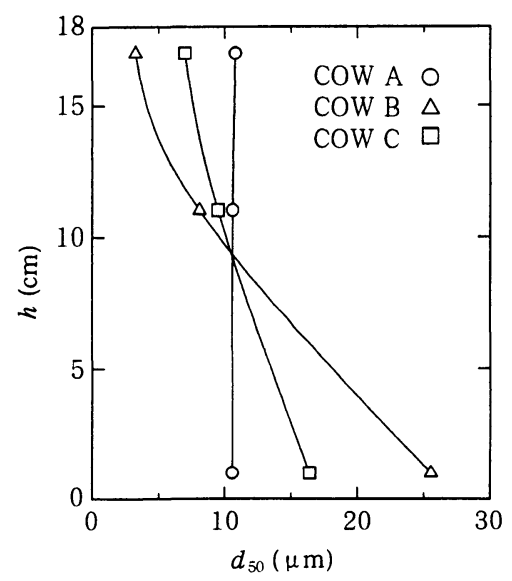

Fig. $350 \%$ diameter of coal particle in $\mathrm{COW}$ after 10 days storage

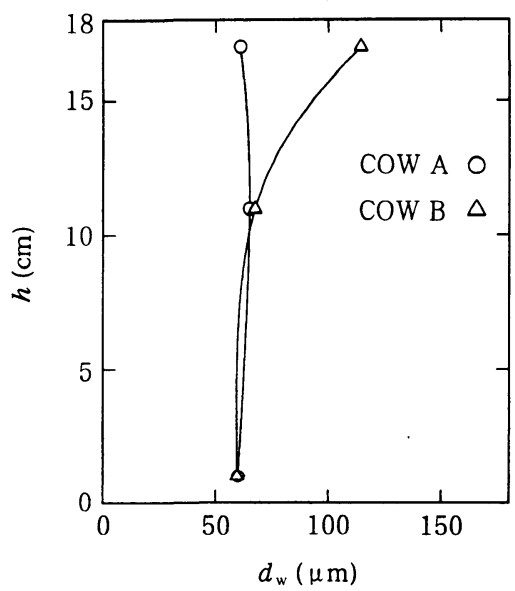

Fig. 4 Maximum diameter of waterdrop in COW after 10days storage

とから，静置安定性は悪いと判定される。

Figs. 3, 4 に, 静置後の COW 中の石炭粒子の $50 \%$ 粒子径 $d_{50}$, 最大液滴径 $d_{\mathrm{w}}$ の測定結果を示す。 $d_{50}$ は, COW 中の石炭粒子をへキサン洗浄した後乾燥し, そ の粒子径分布を遠心沈降法により測定することにより 求められた。 $d_{\mathrm{w}}$ を前報 ${ }^{2)}$ で述へた方法により測定し た。静置安定性の良いCOW A の場合には， $d_{50}, d_{w}$ ともに測定位置の高さ $h$ の違いによる差はほとんど見 られない。一方, 静置安定性の悪い COW B， Cで は， $d_{50}$ はともに試験容器底部で大きくなり，上部で 小さくなっている。これは, 石炭粒子の粒子径が大き いほど沈降が起こり易く，その移動距離も大きいこと

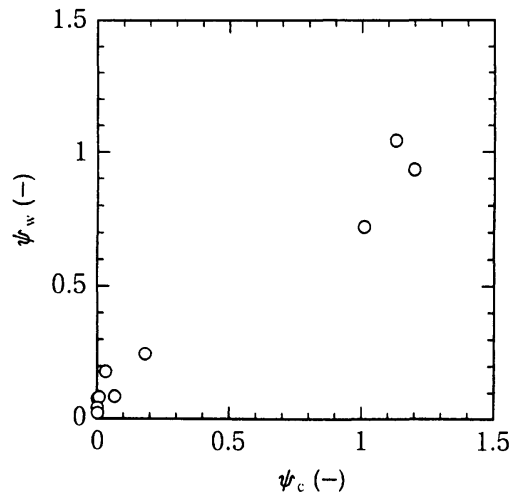

Fig. 5 Relationship between $\psi_{w}$ and $\psi_{c}$

を示すものと言える。COW B に対する $d_{w}$ の值は、 水の容積分率 $\phi_{v w}$ が大きくなる試験容器上部で急激に 大きくなり， $h=17 \mathrm{~cm}$ における $d_{\mathrm{w}}$ は静置前の $d_{\mathrm{w}}$ の 值である $61 \mu \mathrm{m}$ の約 2 倍となっている。これは, $\phi_{v w}$ が大きい試験容器上部では各液滴が接近し，これによ り液滴の合体が進んだためと考えられる。Figs. 3,4 の結果からわかるように, 静置安定性が悪いと判定さ れる場合には, 静置後の COW 中では各成分は均一に 分布しておらず，このような COW を使う場合には， 擋拌などによる COW 中の成分の再均一化が必要であ る。

Fig. 5 に, Eqs. (2), (3) で定義される $\psi_{\mathrm{c}}$ と $\psi_{\mathrm{w}}$ の関

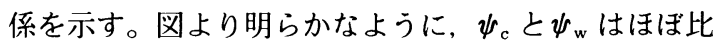
例関係にあり， $\psi_{\mathrm{c}}$ の増大につれて $\psi_{\mathrm{w}}$ も増大すること がわかる。これは前記したように，石炭粒子の沈降之 水滴の上昇が互いに連動した現象であるためである。 これょり， $\psi_{\mathrm{c}}$ の值は $\mathrm{COW}$ 中の全成分の分布状態の 指標となりうると考えられ，成分容積分率測定に基つ く COW の静置安定性の判定を， $\psi_{\mathrm{c}}$ の值に基づいて 行うことは妥当と考えられる。

\section{1.2 棒貫入法試験による判定}

Fig. 6 に，前の 3.1.1 項で検討した 3 種類の COW に 対する棒貫入法試験の測定結果を示す。COW A, C の場合, 所要時間は異なるがそれぞれ貫入棒は試験容 器底部まで達しており, 棒貫入法試験により COW A，Cは共に静置安定性が良いと判定される。COW B の場合には, 貫入棒は貫入棒先端と試験容器底部之 の距離 $h_{\mathrm{r}}$ が $5.9 \mathrm{~cm}$ となったところで停止しており, これより静置安定性は悪いと判定される。貫入棒が $h_{\mathrm{r}}=5.9 \mathrm{~cm}$ のところで停止したのは, $h_{\mathrm{r}} \leq 5.9 \mathrm{~cm}$ の部 分に堅固な石炭粒子のハードパック層が形成されて いるためである。Fig. 2 より，この部分の $\phi_{\mathrm{vc}}$ は 0.45 


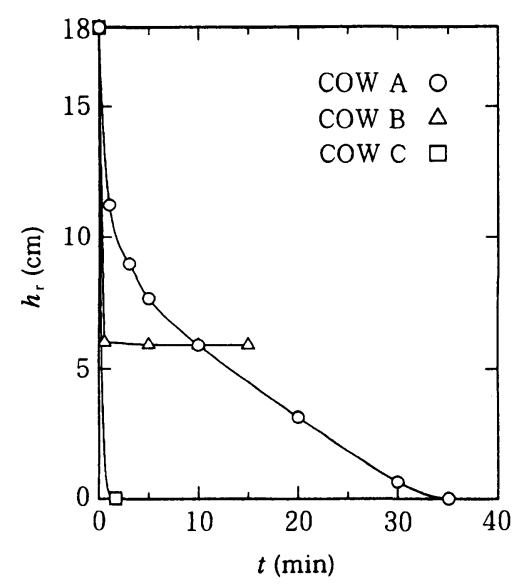

Fig. 6 Rod penetration test

〜0.48であることがわかる。また，本研究全体にお いても，ハードパック層中の $\phi_{\mathrm{vc}}$ は $0.44 \sim 0.48$ の範 囲となった。一方, 脱灰前の粉砕石炭粒子 $\left(d_{50}=\right.$ $11.2 \mu \mathrm{m})$ の空気中で測定されたランダム密充䪺状態 での充填容積分率は，0.43 0.45である。空気中で 測定された充填容積分率の結果を液中に直接適用する ことはできないが，ハードパック層中の $\phi_{\mathrm{vc}}=0.44 \sim$ 0.48 という值は，重油中における石炭粒子のランダム 密充填に扭ける充填容積分率に近い值之考えられる。 このため, ハードパック層は堅固となり，また $\phi_{\mathrm{vc}}$ が 0.48 を超える值にもならないものと考えられる。 COW C に対するFig. 2 と Fig. 6 の結果より, 棒貫入 法試験で静置安定性が良いと判定される場合, それは 再均一化が困難なハードパック層が形成されていない ことを保証するものであり, COW 中での各成分の均 一性を保証するものではないことがわかる。

\section{2 静置安定性についての考察}

Fig. 7 に, 本研究で行った COW の静置安定性試験 の結果を示す。静置安定性は, COW 中の全分散相容 積分率である $\phi_{(\mathrm{vc}+\mathrm{vw}) 0}$ が大きいほど, また静置温度 $T$ が低いほど良いことがわかる。これは連続相である重 油の粘度が温度の低下につれて増大すること, また分 散粒子間に働く相互作用力が，スラリーの流動性の 低下を一層助長することが原因と考えられる。前報 ${ }^{21}$ で示したように， $\phi_{(\mathrm{vc}+\mathrm{vw}) 0}$ が大きく $T$ が低いほど, COW のビンガム流動性が強くなり, 特に降伏值が急 激に増大する。その結果, 分散粒子が COW 中を移動 しにくくなり, 静置安定性が良くなる。

これまで, 石炭スラリーの安定性はスラリーの降伏 值との関係から多くの検討がなされてきたが, そのほ

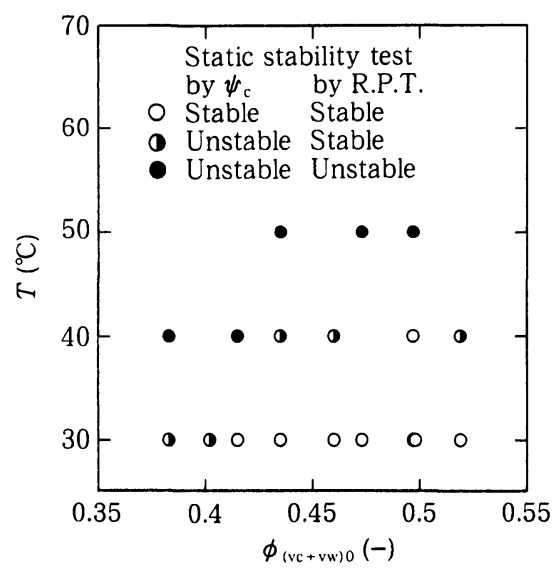

Fig. 7 Results of static stability test of COW R.P.T. : Rod penetration test
とんどは両者の定性的な関係について述べに止まっ ている ${ }^{5,6.8)}$ 。その原因は, ビンガム流体中での沈降現 象の複雑さにあると考えられる。一方, Meyer ら ${ }^{91}$ は, ビンガム流体中の球形粒子を沈降させない降伏值 $\sigma_{y}$ の条件として, 実験結果および粒子に働く力に関 する簡単なモデル化から， Eq. (4) を提案している。

$$
\sigma_{y}>\frac{2}{3} d\left(\rho_{\mathrm{p}}-\rho_{\mathrm{d}}\right) g
$$

ここで， $\rho_{\mathrm{p}} ， \rho_{\mathrm{d}}$ は粒子および分散媒の密度である。 Eq. (4) は, 分散粒子の安定化のための条件を定量的 に論ずることができる点で優れており, 薄井ら゙は Eq. (4) を参考にして CWM の安定性について検討し ている

Fig. 8 は, 本研究で行った静置安定性試験の結果と $\mathrm{COW}$ の降伏值 $\sigma_{y}$, 全分散相容積分率 $\phi_{(\mathrm{vc}+\mathrm{vw}) 0}$ 之の関 係を示したものである。 $\sigma_{y}$ は, 回転粘度計（東京計 器, B8L 型粘度計）を使って測定された值 ${ }^{2)}$ を用い た。 $\sigma_{y}$ の值は COW の静置安定性に影響し, $\phi_{(\mathrm{vc}+\mathrm{vw}) 0}$ が同じ条件では， $\sigma_{y}$ が大きくなると静置安定性が増 す傾向が見られる。図中の破線は，分散石炭粒子に対 して Eq. (4) の右辺を計算した值を示したものであ る。ここで, 粒子径 $d$ としては, COW 中の最大石炭 粒子径である $100 \mu \mathrm{m}$ を用いた。静置温度 $T=30$ $50^{\circ} \mathrm{C}$ において, この計算值はほぼ同じ值となる。破 線の上部には静置安定性が良好な結果が多く, 破線の 下部には $\psi_{\mathrm{c}} \leq 0.1$ となるような安定した $\mathrm{COW}$ は存在 しない。これより，Eq. (4) は COW の静置安定性を 考える場合においても，有効な一つの判断基準を与え るものであるといえる。しかし, 全体的には $\phi_{(\mathrm{vc}+\mathrm{vw}) 0}$ 


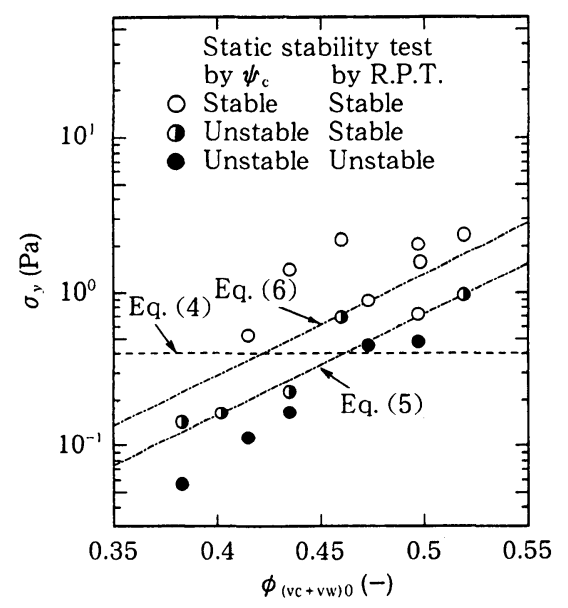

Fig. 8 Influence of $\sigma_{y}$ and $\phi_{(v c+v w) 0}$ on static stability of $\mathrm{COW}$

が大きくなるにつれて，良好な静置安定性を保つに必 要な $\sigma_{y}$ が増大する傾向が見られ，Eq. (4) のように分 散粒子の物性值などから決まる $\sigma_{y}$ の值のみで, $\mathrm{COW}$ の静置安定性が決定されていないことがわかる。この 原因として，以下のことが考えられる。

石炭粒子径 $d=100 \mu \mathrm{m}$ に対する Eq. (4) の右辺の 值である 0.40Pa に比較して, $\mathrm{COW}$ の $\sigma_{y}$ の值が圧倒 的に大きい場合には，COW 中での石炭粒子の沈降は 不可能で, このとき $\psi_{\mathrm{c}} \cong 0$ となって COW の静置安定 性は良くなる。一方， $\sigma_{y}<0.40 \mathrm{~Pa}$ となる場合には， COW 中の石炭粒子は静置期間中沈降することにな る。Fig. 8 の結果より，このような状況は， $\sigma_{y}$ が 0.40Pa よりも若干大きいような条件においても起こ っていることになる。本研究で採用した COW の静置 安定性の判定法では, 静置試験容器の底部付近の堆積 石炭粒子層の充填状態か， 静置安定性の判定に大きく 影響を与える。降伏值 $\sigma_{y}$ が比較的大きい COW の場 合, 分散石炭粒子の沈降速度は小さくなる。しかし, $\sigma_{y}$ が大きいことは $\mathrm{COW}$ 中の平均石炭容積分率 $\phi_{\mathrm{vc} 0}$ が 大きいことにつながり, 静置容器底部の $\phi_{\mathrm{vc}}$ が最初か らハードパック層が形成される $\phi_{\mathrm{vc}}=0.44 \sim 0.48$ に近 いことになる。このため，10日間の静置期間中に， 試験容器底部に $0.44 \sim 0.48$ あるいはそれに近い $\phi_{\mathrm{vc}}$ を 持つ沈降圧密層が形成され，その結果として静置安定 性が悪いと判定されることになる。一方， $\sigma_{y}$ が小さ いCOW の場合には, $\mathrm{COW}$ 中の $\phi_{\mathrm{vc} 0}$ は小さいもの の，分散石炭粒子の沈降速度が大きくなる。このた め, 10 日間の静置期間中に多量の石炭粒子が静置容 器底部に沈降し, 堅固な压密層が形成され, 静置安

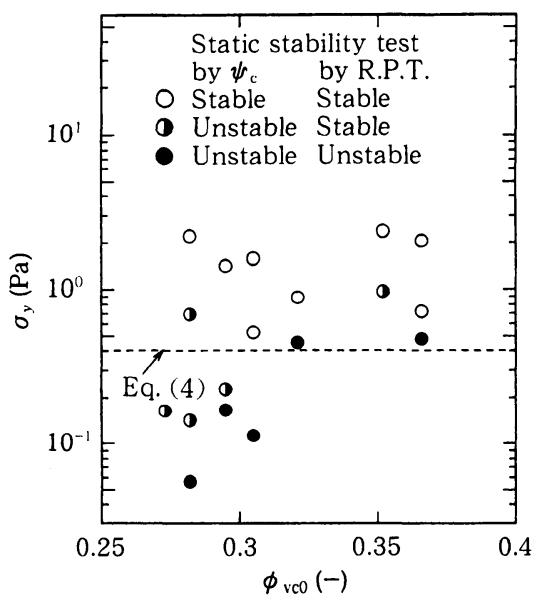

Fig. 9 Influence of $\sigma_{y}$ and $\phi_{v c 0}$ on static stability of $\mathrm{COW}$

定性が悪いと判定されると考えられる。Fig.9は， COW の静置安定性の実験結果を， $\sigma_{y}$ vs. $\phi_{\mathrm{vc} 0}$ のグラ フ上にプロットしたものである。図中の破線は，Fig. 8 と同じく $d=100 \mu \mathrm{m}$ の石炭粒子に対する Eq. (4)の 右辺の計算值を示したものである。全体として、平均 石炭容積分率 $\phi_{\mathrm{vc} 0}$ が大きくなるにつれて, 静置安定性 を保つのに必要な $\sigma_{y}$ の值は大きくなる傾向が見られ る。しかし, 静置安定性の程度を示す 3 種類の記号 の存在領域の区別は，Fig. 8 ほど明瞭でない。これ は, COW の静置安定性は分散石炭粒子の沈降に大き く影響されるものの, 同時に分散水滴の存在によっ ても影響を受けているためと考えられる。分散水滴 の与える影響は，主に沈降石炭粒子とそのために上 昇させられる分散水滴の置換現象に関係していると 考えられる。本研究における COW 中の分散水滴の最 大径である $200 \mu \mathrm{m}$ を使って，分散水滴に対して Eq. （4）の右辺を計算すると，その值は $0.14 \mathrm{~Pa}$ となり,

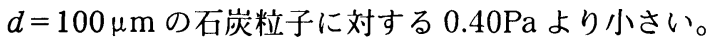
これは，COW の静置安定性が悪い場合，まず粒子径 の大きな石炭粒子が下方へ沈降し，それに伴い分散水 滴が上方へ押し出される置換現象が起こるという考え を支持するものである。

以上の結果より, 本研究で検討した範囲内の $\mathrm{COW}$ の静置安定性は，次の Eqs.（5)，(6) によって分けら れる。

$$
\begin{aligned}
& \log \sigma_{y}>6.6 \phi_{(v \mathrm{c}+\mathrm{vw}) 0}-3.4 \\
& \log \sigma_{y}>6.6 \phi_{(\mathrm{vc}+\mathrm{vw}) 0}-3.2
\end{aligned}
$$

すなわち，Eq. (5) の条件を満たす降伏值 $\sigma_{y}$ を持つ 
COW は，すべて棒貫入法試験で安定と判定された。 また，Eq. (6) を満たす $\sigma_{y}$ を持つ COW は，すべて石 炭容積分率測定に基づく安定性基準である $\psi_{\mathrm{c}} \leq 0.1$ の 条件を満たした。ただし，Eqs. (5)，(6) は静置期間 が 10 日間の場合に対して適用されるものであり, 静 置期間が異なる場合には，Eqs. (5), (6) の式形も異 なってくると考えられる。また，COW 中の石炭粒子 の粒子径分布などが本研究のものと異なる場合にも,

Eqs. (5)，(6) の式形は異なってくると考えられる。

\section{4. 結言}

脱灰石炭造粒粒子から製造された COW（石炭一重 油一水混合物) の静置安定性について, 静置後の静置 安定性試験容器の上部と下部の石炭容積分率の差を使 って定義される静置安定性指数 $\psi_{\mathrm{c}}$ に基づく判定の結 果, および棒貫入法試験により検討を加えた。これに より, 以下の 1）～3）の結果を得た。

1） $\psi_{\mathrm{c}} \leq 0.1$ となって， $\psi_{\mathrm{c}}$ の值に基づく判定法で静置
安定性が良いと判定されるCOW の場合, 試験容器 内の各高さにおける不炭粒子および水滴の容積分 率, 粒子径は, 静置前後でほぼ同じ值となった。一 方, $\psi_{\mathrm{c}}>0.1$ となって静置安定性が覀い場合, 石炭 容積分率は試験容器下部で大きくなり, 水の容積分 率は試験容器上部で大きくなった。

2）棒貫入法試験で静置安定性が良いと判定される場 合には, 静置後の COW 中に石炭粒子のハードパッ ク層の形成は見られない。しかし，それは COW 中 の各成分の分布の均一性を保証するものではない。

3） COW の静置安定性は, COW の降伏值により大き く影響され, 分散粒子の沈降性と降伏值との関係を 示した Meyer らの判別式が, COW の静置安定性 に対しても一応の判定基準を与えることが確認され た。一方, COW の静置安定性を良い状態に保つの に必要な降伏值は, COW 中の全分散相容積分率に 影響された。本研究で検討した COW の安定性の程 度を区別するための実験式を得た。

\section{Nomenclature}

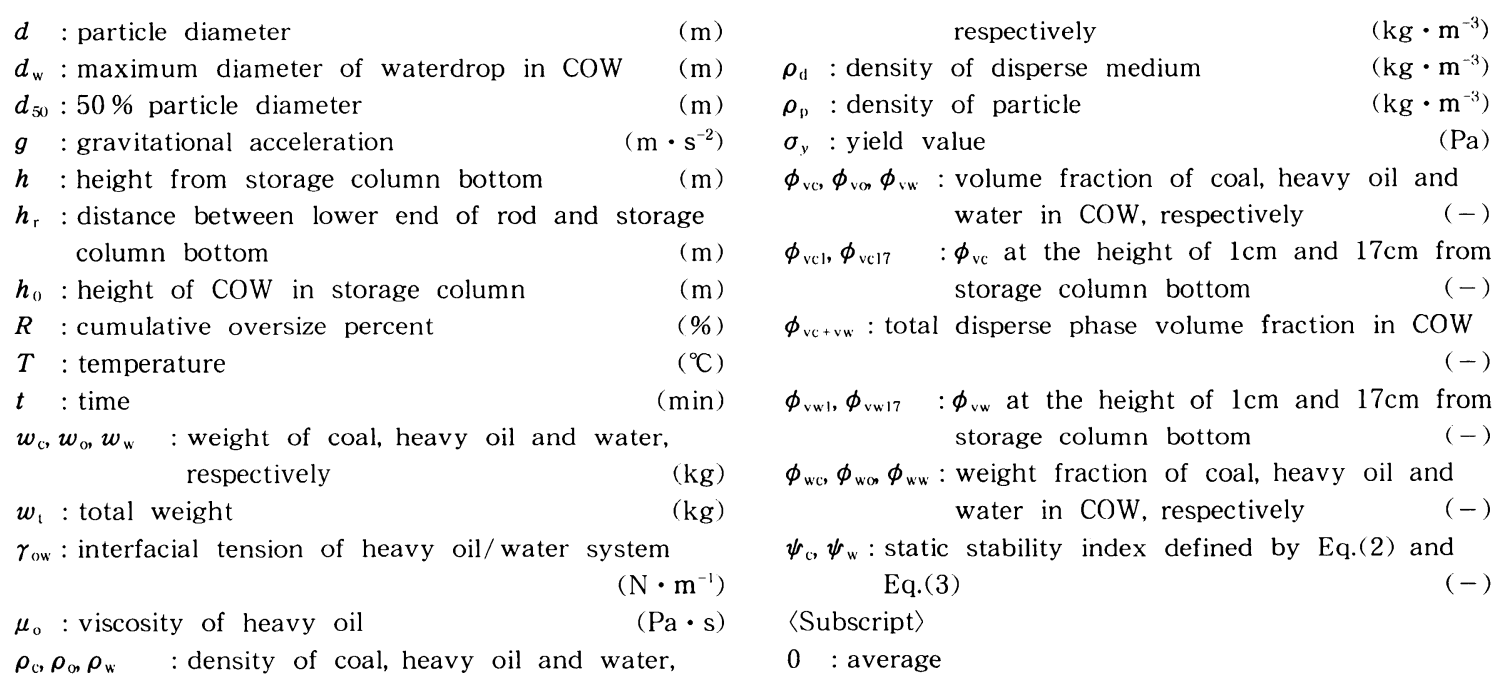

\section{References}

1) Division of Coal Science and Technology : "Coal Production and Technology 1996", Shigen to Sozai, 113, 723-731 (1997)

2) Takase, H. and S. Miyazaki : "Flow Characteristics of Coal-Oil-Water Mixture Prepared by Disintegration of Deashed Coal Agglomerates", J. Soc. Powder Technol., Japan, 35, 856-863 (1998)

3 ) Capes, C. E., A. E. Mcllhinney and R. D. Coleman : "Beneficiation and Balling of Coal", Trans. AIME, 247, September, 233-237 (1970)
4) Takase, H., K. Higashi and M. Sugimoto: "Study on the Deashing of Coal by the Oil Agglomeration Process", J. Soc. Powder Technol., Japan, 28, 430-436 (1991)

5 ) Takeshita, T., S. Maeda, M. Imayoshi, Y. Mitsuo, Y. Katayama and T. Kamikawa: "Effects of Additives on Sedimentation Stability of COM (II)", J. Japan Petrol. Inst., 26, $384-389$ (1983)

6 ) Takezaki, H., H. Kikkawa, Y. Otani, K. Sato and K. Shoji: "Study on Storage Stability of Cleaned 
CWM", J. Soc. Powder Technol., Japan, 24, 783-787 (1987)

7 ) Usui, H., T. Saeki and Y. Sano: "Stability Evaluation of Coal-Water Mixtures by Internal Structural Stress", J. Chem. Eng. Japan, 21, 602-607 (1988)

8 ) Naka, A., H. Sugiyama and Y. Nishida: "Yield Point and Stability of Highly Loaded Coal-Water Mixture (CWM)”, Nippon Kagaku Kaishi, No. 5, 899-904 (1987)

9 ) Meyer, R. J. and L. Cohen: "The Rheology of Natural and Synthetic Hydrophilic Polymer Solu tions as Related to Suspending Ability", J.Soc. Cosmetic Chemists, 10, 143-154 (1959) 